\title{
Kritik Karl Marx Terhadap Kapitalisme dan Pengertian Sosialisme
}

\author{
Rezki Amalia Fathurrahman (90100118108)
}

Email: rezkiamalia56@gmail.com

\begin{abstract}
Abstrak
Adanya teori sosialisme itu dimulai dari kritik Karl Marx terhadap kapitalisme, yang dimana Karl Marx mengkritik dua hal dari kapitalisme. Pertama tentang teori nilai tambah dan kedua, perkembangan kapitalisme yang menyebabkan terjadi kontrakdiksi antara kaum pemilik modal dan kaum buruh. Pada teori nilai tambah ini Karl Marx mengutip teori dari David Ricardo yang dimana menurut Ricardo bahwa terjadi nilai tambah karena adanya nilai komoditas suatu produksi bukan ditentukan karena adanya usaha yang dilakukan dengan sedikit pengorbanan tetapi karena adanya usaha yang dilakukan sebelumnya terhadap produksi barang terhadap alat dan perlengkapan yang digunakan. Jadi Karl Marx menyimpulkan bahwa terjadi nilai tambah terhadap komoditas tergantung berapa jumlah tenaga kerja atau bertambah produktivitas tenaga kerja, karena semakin banyak tenaga kerja maka semakin tinggi nilai komoditas tetapi permasalahannya munculnya eksploitasi dan aliensi karena kaum kapitalis memiliki pandangan bahwa ia bisa menggambil tenaga kerja atau menambah jam kerja jika memiliki modal dan alat produksi yang memuncul keterasingan kaum buruh dan perbedaan kelas antara kaum pemilik modal dan kaum buruh. Perkembangan kapitalisme yang menyebabkan terjadi kontradiksi ini karena kapitalis memiliki tujuan awal untuk melakukan perbaikan untuk mengurangi permasalahan yang sedang terjadi tetapi tidak mampu untuk menyelesaiakan permasalahan tersebut sehingga muncul kontradiksi antara pemilik modal dan kaum buruh karena pandangan kapitalisme ini. Maka dari itu muncul teori yang bernama sosialisme yang dikembangkan oleh Karl Marx yang teori menganut hak kepemilikan bersama.
\end{abstract}

Kata Kunci: Karl Max; Sosialisme; Kapitalisme 


\section{Pendahuluan}

Kritik Karl Marx terhadap Kapitalisme dimulai dengan Karl Marx menjelaskan tentang nilai guna dan nilai tukar terhadap suatu komoditas atau barang yang dimana menurut pendapatnya bahwa nilai guna adalah suatu barang yang digunakan untuk dipakai sedangkan nilai tukar adalah barang yang memiliki nilai ekonomis dengan kata kali bisa untuk dijual, selain itu Marx menilai bahwa antara pemilik modal dan buruh adalah memiliki antara transaksi yang dapat diperjualbelikan yang terkadang kaum buruh merasa tereksploitasi oleh kaum pemilik modal (Qomar, 2019). Selain itu Karl Marx mengemukakan sebuah ide yang berhubungan dengan kapitalisme yang dimana terdiri atas tiga yaitu manusia, sumber alam dan alat produksi jika digabungkan makanya akan menghasilkan suatu barang dimana diperlukan adanya tenaga kerja, bahan mentah untuk produksi dan alat produksi, jika terjadi permasalahan seperti konflik antara kaum pemilik modal dan kaum buruh maka akan terjadi revolusi sosial atau pemberontakan yang dilakukan oleh kaum buruh karena adanya eksploitasi (Rachmawati, 2020). Karl Marx juga mengkritik terhadap Agama alasannya karena Agama bekerjasama dengan penguasa ekonomi untuk menindas umat manusia dan menganggap agama yang mengajarkan manusia untuk menerima nasib hidupnya menjadi miskin dan terhina yang bekerjasama dengan kapitalis membiarkan kemiskinan terjadi (Bahtiyar \& M. Mu'inudinillah Basri, 2015).

Setelah Karl Marx mengkritik terhadap kapitalisme maka lahir yang bernama sosialisme. Yang dimana sosialisme muncul pada awal abad 19 yang merupakan salah solusi terhadap kapitalisme karena kapitalis di anggap gagal mewujudkan masyarakat sejahtera meskipun muncul golongan sosialis ada yang sosialis moderat atau penengah yang masih memperjuangkan idealisme dan adapula sosialis ekstrim yang berusaha mewujudkan idealisme sehingga terjadi revolusi (Wikandaru \& Cahyo, 2016). Konsep sosialisme juga pernah digunakan oleh Sayyid Qutbh seorang syekh sekaligus pemikir yang mencetuskan pemikiran sosialisme yang menurut bahwa Sosialisme adalah salah solusi untuk mengatasi ketimpangan sosial sehingga terjadi perbedaan kelas sosial meskipun ada beberapa 
yang menentang idenya mengenai konsep sosialisme ini karena dianggap sosialisme adalah pemikiran dari luar yang tidak cocok untuk diterapkan di negara Islam (Asnawiyah, 2013). Teori sosialisme yang dikembangkan oleh Karl Marx di kaji ulang karena adanya teori sosialisme yang semula untuk mensejahterakan masyarakat berubah menjadi sosialisme ekstrim menuju komunisme (Nazsir, 2001) 


\section{Pembahasan}

Karl Marx mengkritik sistem kapitalisme terhadap proses produksi terbagi atas dua yaitu, nilai tambah yang dimana Karl Marx mengutip dari teori David Ricardo yang mengatakan bahwa terjadi nilai tambah terhadap komoditas bukan karena usaha yang sudah dilakukan melainkan usaha yang dilakukan sebelumnya terhadap alat produksi untuk melakukan kegiatan produksi, selain itu Karl Max menyoroti rumus $\mathrm{M}-\mathrm{C}-\mathrm{M}$ yaitu rumus yang digunakan oleh kaum kapitalis untuk mendapatkan keuntungan sehingga kaum buruh ini merasa tereksploitasi karena harus menambah tenaga kerja atau ditingkatkan produktivitas kerjanya sehingga memunculkan kontradiksi karena adanya esensi kapitalisme adalah melakukan penambahan modal dengan cara menambahkan tenaga kerja untuk menghasilkan suatu barang (Kambali, 2020). Karl Marx juga mengkritik tentang Agama yang menurut pendapatnya bahwa Agama telah memanupulasi manusia terhadap realitas hidup yang sebenarnya atas pengharapan dimasa depan yang bersifat hakiki dan akan abadi di kemudian hari dan menurutnya agama akan membuat manusia akan berpikir lebih jauh dari realitas hidup yang sebenarnya, alasan Karl Marx karena agama mengajarkan memasrahkan kepada keadaan dibandingkan melakukan usaha memiliki materi seperti barang sehingga agama dianggap candu dan pasrah terhadap keadaan meskipun memiliki kekurangan dari segi materi (Muttaqin, 2013).

Setelah Karl Marx mengkritik mengenai sistem kapitalis maka lahirlah yang bernama sosialisme yang dimana sosialisme adalah suatu sistem yang dimana bahwa segala sumber daya alam dan alat produksi adalah kepemilikan bersama sehingga perekonomian dapat dijalankan dengan yang dimana sosialisme memiliki prinsip bahwa setiap orang berhak mendapatkan imbalan atau hasil usaha yang sama sehingga pemerintah ikut mengontrol jalannya perekonomian dari definisi tersebut dijelaskan bahwa sosialisme adalah terjadinya transaksi atau di pasar harus dikontrol melalui perencanaan terpusat yang dilakukan pemerintah (Subandi, 2018). Menurut Tjokrominoto bahwa ia melihat sosialisme dan Islam sebagai penggabungan antara dua pemikiran yaitu ajaran sosialisme yang berasal dari Barat 
dan ajaran Islam karena menurutnya bahwa Sosialisme adalah cita-cita Islam yang sudah dilakukan sejak lama dan tidak dapat dikatakan bahwa sosialisme muncul dari eropa (Wijiyanto \& Sudrajat, 2019). Tujuan dari sosialisme adalah untuk menjaga kelangsungan hidup masyarakat dan produksi yang dilakukan tergantung kebutuhan masyarakat (Nurul Cholidiyah dan Richa Angkita Mulyawisdawati, 2018) 


\section{Kesimpulan}

Bahwa lahirnya sosialisme itu dilatarbelakangi dengan adanya kritik Karl Marx terhadap kapitalisme yang dimana menurut pendapatnya kaum pemilik modal melakukan eksploitasi terhadap kaum buruh sehingga terjadi kontradiksi antara kaum buruh dan kaum pemilik modal yang dimana pada akhirnya muncul yang bernama sosialisme yang dinama sosialisme adalah sistem ekonomi yang mengakui kepemilikan bersama maka dari pemerintah mengontrol jalan perekonomian dan segala kegiatan ekonomi harus berpusat pada perencanaan yang dilakukan pemerintah. 


\section{Daftar Pustaka}

Asnawiyah. (2013). Konsep Sosialisme Islam Menurut Sayid Qutbh. Jurnal IlmuIlmu Ushuluddin, 15(1), 53-65. http://substantiajurnal.org/index.php/subs/article/download/6/5

Bahtiyar, E., \& M. Mu'inudinillah Basri, dan S. H. (2015). Kritik Islam Terhadap Konsep Marxisme tentang Pengentasan Kemiskinan. Profetika, Jurnal Studi Islam, 16(2), 127-135. http://digilib.uin-suka.ac.id/15760/1/10510008_babi_iv-atau-v_daftar-pustaka.pdf

Kambali, M. (2020). Pemikiran Karl Marx Tentang Struktur Masyarakat (Dialektika Infrastruktur Dan Suprastruktur). Jurnal Pemikiran Dan Penelitian Ekonomi Islam, 8(2), 63-80. https://media.neliti.com/media/publications/332489-pemikiran-karl-marxtentang-struktur-mas-fb1b694e.pdf

Muttaqin, A. (2013). Karl Marx Dan Friederich Nietzsche Tentang Agama. KOMUNIKA: Jurnal Dakwah Dan Komunikasi, 7(1), 1-10. https://doi.org/10.24090/komunika.v7i1.365

Nazsir, N. (2001). Komunisme Sebuah Utopia dalam Era Globalisasi : Tinjauan Historis terhadap Pemikiran Karl Marx. Tinjauan Historis Terhadap Pemikiran Karl Marx, 2(2), 245-265.

Nurul Cholidiyah dan Richa Angkita Mulyawisdawati. (2018). Perilaku Produsen Menurut Yusuf Qordhowi dan Karl Marx. Laa Maisyir, 5(2), 68-88.

Qomar, M. N. (2019). Kritik Karl Marx Terhadap Konsep Buruh Kapitalis Kajian Komparatif Ekonomi Syariah Atas Buku Das Kapital. Annual Conference for Muslim Scholar 3 Kopertais 4, 3(1), 1003-1009.

Rachmawati, F. (2020). Kritik terhadap Konsep Ideologi Komunisme Karl Marx. Jurnal Sosiologi Agama Indonesia (JSAI), 1(1), 66-78. https://doi.org/10.22373/jsai.v1i1.424

Subandi. (2018). Sistem Ekonomi Indonesia. Alfabeta.

Wijiyanto, S. T., \& Sudrajat, A. (2019). Tjokroaminoto : Sosialisme Islam. Bihari: Pendidikan Sejarah Dan Ilmu Sejarah, 2(1), 1-12.

Wikandaru, R., \& Cahyo, B. (2016). Landasan Ontologis Sosialisme. Jurnal Filsafat, 26(1), 112. https://doi.org/10.22146/jf.12627 